\title{
A precíziós genomszerkesztés mezőgazdasági alkalmazásának szabályozási alapkérdései és az elővigyázatosság elve
}

\author{
génszerkesztés - elővigyázatosság elve - fötanácsnoki indítvány - \\ az EU Bíróság ítélete
}

A rohamosan fejlődő génmanipulációs technikák (génmódosítás, géntechnológiai módosítás) régóta viták kereszttüzében állnak, amit a jogi szabályozás alakulása is tükröz. A géntechnológiai módosítás a géntechnológiai tevékenységről szóló 1998. évi XXVII. törvény (a továbbiakban: Géntv.) 2. §g) pontja szerint olyan eljárás, amely a gént vagy annak bármely részét kiemeli a sejtböl és átülteti egy másik sejtbe, vagy szintetikus géneket, vagy génszakaszokat visz be valamely természetes szervezetbe, ami által a befogadó génállománya megváltozik. Mint alább látni fogjuk, az EU vonatkozó irányelve a génmódosítást (az eljárást) nem definiálja, ugyanakkor az eredményére (a génmódosított szervezetre, GMO-ra) ad egy meghatározást, $\mathrm{s}$ bizonyos technikákat felsorol, mint amelyek génmódosítást eredményeznek. A jogi definíció elsődleges funkciója mindkét esetben a szabályozás tárgyi hatályának kijelölése, ami álláspontom szerint nem a nemesítők és a biotechnológusok, hanem a jogtudomány, illetve a jogalkotó feladata. ${ }^{1} \mathrm{~A}$ vitás kérdések napjainkban még a fogalomalkotásra is kiterjednek sőt, ezek az igazán izgalmas kérdések.

Mielött ezekre rátérnék, szükségesnek látom a háttér rövid bemutatását. A géntechnológiát több (orvosi, mezőgazdasági, ipari stb.) területen is alkalmazzák, amely alkalmazási területek közül például a „zöld géntechnológiának” (a géntechnológia mezőgazdasági alkalmazásának) és az így elóállított fajták - GMO-k - termesztésének, az azokból elóállított termékek forgalmazásának az európai szabályozása az EU és az USA (illetve a Világkereskedelmi Szervezet) közti parázs vitában formálódott. Ez a kezdeti (1990-ig tartó) teljes uniós tiltástól egy megengedő szabályo-

* Dr. Fodor László egyetemi tanár, Debreceni Egyetem Állam- és Jogtudományi Kar Agrárjogi, Környezetjogi és Munkajogi Tanszék, fodor.laszlo@law.unideb.hu. A tanulmány alapjául szolgáló kutatást az Emberi Erőforrások Minisztériuma által meghirdetett Felsőoktatási Intézményi Kiválósági Program támogatta, a Debreceni Egyetem 4. tématerületi programja keretében.

1 Nem értek ezért egyet (jogi szempontból) Dudits Dénes akadémikus véleményével, amely szerint (a nemesítés hagyományos technikáira is kiterjesztve a fogalmat) „[a] tudomány túllép a GMO-vitán ... valamennyi tenyésztett állatunk, termesztett növényünk genetikailag módositott szervezet, tehát GMO... Ezért, ha lenne szakmai hitele az Alaptörvény XX. cikkelyében olvasható szavaknak [...], akkor hazánk nem GMO-mentes, hanem mezögazdaságmentes lenne." Zöldbiotech, 2016. 09. 20., http://www.zoldbiotech.hu/cikk/388-Atudom-ny-t-II-p-a-GMO-vit-n (2018. 03. 02.). 
záson, majd az ún. „de facto moratóriumon” (1998-2004) át számos GM-termék importja és kereskedelme, illetve több GM-növényfajta engedélyezéséig vezetett. ${ }^{2}$ A jelenlegi uniós szabályozás bizonyos (idegen gén beültetésével nem járó, kevésbé aggályos) technikákat nem érint, míg a többségre fő szabályként az elővigyázatosság elvén alapuló engedélyezési, kimutathatósági, felügyeleti, jelölési stb. követelmények vonatkoznak. ${ }^{3}$

A szabályozási vita másik frontja az EU és egyes tagállamai között alakult ki; főbb állomásai pedig az EU-jog alapján engedélyezett fajták termesztésének a tagállami eszközökkel történő, részben jogszerü, részben jogellenes tiltása, európai bírósági elmarasztalások, ${ }^{4}$ majd 2015 -töl a tagállami mozgástér növekedése. Egyes tagállamok nyitottak, mások elzárkóznak ma is, nemcsak tudományos szempontból, hanem részben etikai okokból, részben a GM-mentes mezőgazdaság európai versenyelőnye érdekében. A GM-termesztésbe vont európai termőterületek kiterjedése egyébként elenyésző a világ összes érintett területéhez képest. ${ }^{5}$

A viták folynak tovább, hiszen az elsődlegesen érintettek (a nemesítők) igyekeznek saját szempontjaikat érvényesíteni. Az új nemesítési eljárásokat alkalmazó vállalkozások kiemelik a géntechnológia alkalmazásának előnyeit, úgymint, például a terméshozamok növekedését, a környezeti terhek (vegyszerek, üvegházhatású gázok) csökkenését, a klímaváltozáshoz való alkalmazkodást (szárazságtürő fajták), s gazdasági érdeküknek megfelelően igyekeznek az előttük álló akadályokat elhárítani, igénybe véve szakértőket, a nemzetközi vitarendezési mechanizmusokat, lobbierejüket is. A tengerentúli termelők versenyelőnyét állítják szembe saját

2 A szabályozás múltjának áttekintésére lásd SzILÁGYI János Ede: A zöld géntechnológiai szabályozás fejlődésének egyes aktuális kérdéseiröl. Miskolci Jogi Szemle, 2011/2, 40-52.

3 Az elővigyázatosság elve alapján az a vélelem érvényesül, hogy valamennyi GMO veszélyt hordoz magában, aminek a hiányát vagy elfogadható mértékét a fajtatulajdonosnak kell bizonyítania. Az elővigyázatosság elve az uniós szabályozásban az engedélyezési eljárás részeként érvényesül. Magyarországon az, hogy tilos a GMO-k termesztése, egy lépéssel korábban juttatja szerephez az elvet. Az elv ellentéteként az USA-ban egészen a legutóbbi időkig a lényegi azonosság elve érvényesült, ami azt jelenti, hogy (amíg nem bizonyítottak a káros hatások) nem tesznek különbséget a GM és hagyományos fajták termesztése, kereskedelme és felhasználása közt. Ezt az elvet törte meg előbb néhány bírói ítélet (2010-ben több fajta termesztését is megtiltották), majd 2016-ban az az előírás, amely szerint a GM-termékeket a fogyasztók számára jelölni kell már az USA-ban is. HESzKY László: Transzgénikus (GMO) növények - elmélet és gyakorlat. Agrofórum, Budapest, 2017; HESZKY László: A GMO-növényekről tárgyilagosan. Agrofórum, 2013/12, 64; BÁndı Gyula: Hungary (IEL Environmental Law National Monographs). Kluwer Law International, Alphen aan den Rijn, 2016, 210; SzILÁGYI János Ede-TóтH Enikő: A GMO-mentes mezőgazdaság megteremtésének újabb jogi eszköze: A GMO-mentes termékek jelölése Magyarországon. Publicationes Universitatis Miskolciensis Series Juridica et Politica, Tom., 2017/35, 490-491. Az uniós döntéshozatali mechanizmus szakmai megalapozásának kritikáját lásd TANKA Endre: Adalékok a génmódosított növények hazai köztermeszthetőségéhez. Gazdaság és Jog, 2007/3, 20-26.

4 FodOR László: A GMO szabályozással kapcsolatos európai bírósági gyakorlat tanulságai. In: Csák Csilla (szerk.): Jogtudományi tanulmányok a fenntartható természeti erőforrások témakörében. Miskolci Egyetem, Miskolc, 2012, 65-75.

5 2015-ös adatok szerint a GM-növények termesztése túlnyomóan (98\%-ban) tíz, Európán kívüli országban zajlik. Az EU-n belül Spanyolország az első (a világrangsorban tizenhatodik), a világ GM-termesztéssel érintett összes területének 0,1\%-ával. A cseh, román és szlovák területek alig érik el a 0,001\%-ot. Itt mintegy 100000 ha területről van szó, miközben csak az USA-ban kb. 85 millió hektárról, https://gmoinquiry.ca/wpcontent/uploads/2015/03/where-in-the-world-gm-crops-foods.pdf (2018. 03. 03.). 
világpiaci hátrányukkal, ami a géntechnológiára vonatkozó korlátozásokból, illetve (a legújabb technológiák vonatkozásában) a - szerintük - lassú európai jogalkotásból fakad. Velük szemben a természetvédők, ökológiai gazdálkodók s mások a természeti (az ökoszisztémára kifejtett) és az élelmezés-egészségügyi kockázatokra (például allergizációra), a jelentős exportterméknek számító vetőmagok tisztaságára és az ökológiai gazdálkodást érő károkra (amelyek például a génszökésből, „genetikai környezetszennyezésből” vagy az örökítőanyagban esetlegesen előidézett, nem szándékolt változásokból, a vegyszerrezisztens fajták terjedése miatt a vegyszerhasználatból fakadnak) s további szempontokra is hivatkoznak. ${ }^{6}$

$A z$, hogy messze nem csak erkölcsi vagy akadémikus jellegű a vita, abból is adódik például, hogy az EU komoly mennyiségben importál GM-szójafehérjét a takarmányozáshoz, ami jelentősen olcsóbb a nem GM-szójából készült termékhez képest. (Magyarország importszükségletét GM-mentes termékekből kívánja kielégíteni, illetve ösztönzi a hazai fehérjenövény termesztést). ${ }^{7} \mathrm{~S}$ még egy pénzügyi természetü adalék: mintegy tíz évvel ezelőtt, amikor tucatnyi európai ország a GM-növényekkel kapcsolatos korlátozásokról döntött, tetemes mértékben zuhant a New York-i értéktőzsdén a technológia élharcosának számító cég részvényeinek az árfolyama. ${ }^{8}$

A géntechnológia, illetve a GM-szervezetek termesztése melletti és elleni további érveket $\mathrm{s}$ a bonyolult szabályozás részleteit itt nem áll módomban részletesen áttekinteni. ${ }^{9}$ Hazánk hivatalos álláspontja (amely mögött sajátos érvként kezdetektől jelen volt, s alighanem továbbra is érvényes a Kárpát-medence sajátosan gazdag élővilágának, génörökségének védelme) mindenesetre közismert az ügyben. Bár az uniós jog átültetése megtörtént, a más tagállamokban legalizált, például kukoricafajták köztermesztésbe vonását soha nem engedélyeztük; pert indítottunk és nyertünk az Amflora burgonya kapcsán hozott, megengedő uniós döntés ellen; támogattuk az uniós joganyag megváltoztatását; az elvben megengedő törvényi szabályozás mellett átmeneti tilalmat érvényesítettünk (védzáradék); szigorú koegzisztenciaszabályok kerültek a géntörvénybe; az Alaptörvénybe pedig bekerült a génmódosított szervezetektől mentes mezőgazdaság követelménye. ${ }^{10}$ Ez az elkötelezettség persze nem élvez teljes támogatottságot, hiszen vannak, akik szerint szakmailag nem megalapozott a döntés, lemondunk a mezőgazdaságot előre vivő - a precíziós gazdálkodáshoz ${ }^{11}$ tartozó, egyes - csúcstechnológiákról (amelyek nélkül, úgymond,

6 http://www.biokultura.org/hu/rss-feed/77-hirek/975-sajtokozlemeny-ifoam-gmo-uj-technologiak; https://www. ifoam.bio/en/news/2018/01/11/organic-food-and-farming-movement-calls-regulation-new-genetic-engineering (2018. 02.18.).

7 A szójatakarmány szabályozási helyzetére lásd PÁczAY György Bertalan: Újabb politikai lépés a saját GMOmentes takarmány megteremtése felé. Agrár- és Környezetjog, 2017/22, 102-131.

8 Popp József: A szója szerepe a hazai takarmányozásban. In: Darvas Béla (szerk.): A GM-növények engedélyezésének európai/hazai tapasztalatai. Magyar Ökotoxikológiai Társaság, Budapest, 2017, 27-29; TAHYNÉ KovÁcs Ágnes: A genetikailag módosított szervezetekre vonatkozó szabályozásról. HVG-ORAC, Budapest, 2016, 26.

9 Erre lásd többek közt SzILÁGYI: i. m., 38-54; TAHYNÉ KovÁcs: i. m., 56-61.

10 SZILÁGYI-TótH: i. m., 484-488; TAHYNÉ KovÁcs: i. m., 100-104, 237-240, 280-289; Fodor László: Környezetjog. Debreceni Egyetemi Kiadó, Debrecen, 2014, 111-112, 301-307.

11 A precíziós gazdálkodás kifejezés a hazai jogirodalomban még nem honosodott meg, és értelmezése nem egységes nemzetközi szinten sem. Modern, például az erőforrások (műtrágya, öntözővíz, növényvédő sze- 
a hazai mezőgazdaság skanzenné válik), s rontjuk mezőgazdaságunk versenyképességét. ${ }^{12}$

Ilyen előzmények után, illetve körülmények közepette jelentek meg olyan újabb, nemesítési (genomszerkesztési, génmérnöki) technikák (például a már hazai laboratóriumokban is alkalmazott CRISPR/Cas9) a diskurzusban, amelyek a "hagyományos", korábban definiált génmódosításhoz képest precízebbek, biztonságosabbak, nem járnak idegen gének (más fajok örökítőanyagának) beültetésével, s eredményük nem is GMO - a támogatói oldal, így újabban az MTA Elnökség álláspontja szerint. ${ }^{13} \mathrm{~A}$ másik oldal ehhez képest úgy látja, hogy a génmódosításhoz, illetve a GMO-khoz hasonló, szigorú, illetve tiltó-korlátozó szabályozásra van szükség ezek esetében is, hiszen ezek az új eljárások is ugyanazon kérdéseket vetik fel, eredményük is GMO: így különösen ezeknél is elöfordulhatnak nem szándékolt következmények, s az újabb technikákkal létrehozott termékeknek sincs helyük a biotermékekben, illetve az ökológiai gazdálkodásban. ${ }^{14}$

$E$ tanulmányban génszerkesztés alatt ezeket az új (precíziós génmódosításnak, célzott mutagenezisnek is hívott) technikákat értem; az ezek szabályozásával kapcsolatos, elemi kérdéseket igyekszem feltenni és megválaszolni. A genomszerkesztésnek - mint arra már utaltam - többféle alkalmazási területe van (mezőgazdasági, orvosi alkalmazások, mikrobiális fermentációs biotechnológia), amelyek közül a ma-

rek stb.) precíz, a (táblán belül is változó) talajadottságokhoz és fajtatulajdonságokhoz igazodó kimérését, kijuttatását lehetővé tevő technológiák alkalmazását jelenti. Hazánkban csak az utóbbi években kezdett terjedni ez a gazdálkodási forma (lásd erre például az Agrárgazdasági Kutatóintézet kutatásait; https://www. agronaplo.hu/hirek/a-precizios-gazdalkodas-elterjedese-es-alkalmazasa-magyarorszagon). Nálunk (szemben az USA-beli példákkal) egészen biztosan nem fogalmi eleme a GM-növényfajták alkalmazása.

12 „A hazai géntechnológiaellenes állami döntéshozatal a szakmaiatlan rövidlátás diadala” - írja a tőle megszokott, erős stílusban Dudits Dénes: Génművesség és a modern növényfajták születése. In: Dudits Dénes (szerk.): Zöld géntechnológia és agrárinnováció. Barabás Zoltán Biotechnológiai Egyesület, Szeged, $2009,82$.

13 Precíziós gén- és genomszerkesztés az élhetőbb világért - a Magyar Tudományos Akadémia állásfoglalása. Budapest, 2017. december 6., http://mta.hu/tudomany_hirei/precizios-gen-es-genomszerkesztes-az-elhetobbvilagert-a-magyar-tudomanyos-akademia-allasfoglalasa-108320 (2018. 02. 28.). A támogató vélemények között - nem kis bizonytalanságot okozva - a sajtóban megjelent az agrárminiszter 2018. májusi, miniszteri meghallgatásán tett nyilatkozata is, amelyet azonban nem tekinthetünk a tárca hivatalos álláspontjának, annál is inkább nem, mert később az uniós bírósági ítéletre a miniszter már ellentétesen reagált, üdvözölve a döntést, https://www.agrarszektor.hu/noveny/darazsfeszekbe-nyul-8211-nagy-istvan-szerint-az-uj-gentechnikanem-gmo.10842.html; https://www.agrarszektor.hu/europai-unio/genszerkesztes-ezt-sem-szabad.11300.html; https://www.magro.hu/agrarhirek/gazdalkodas/zoldseg-gyumolcs/genszerkesztes-magyar-kerteszet/; http:// www.zoldbiotech.hu/cikk/507-Drasztikus-eredm-nyroml-s-a-f-ldeken-J-het-a-g-nszerkeszt-s; illetve lásd még a május 14-ei bizottsági meghallgatás jegyzőkönyvét, 35, http://www.parlament.hu/documents/static/biz41/ bizjkv41/MGB/1805141.pdf (2018. 07. 30.).

14 Leegyszerüsítve ez volt a problémafelvetése az Új nemesítési technikák és a génmódosítás című mühelykonferenciának 2018. 02. 19-én, az Alapvető Jogok Biztosának Hivatalában, melynek nyomán a jövő nemzedékek szószólója közleményt bocsátott ki, felhíva a figyelmet, hogy a génszerkesztésre vonatkozóan - is - az elővigyázatosság elvét érvényesítő szabályozás indokolt. Jelen tanulmánynak is ez a konferencia az apropója, amennyiben az ott elhangzott előadásom szerkesztett, s az időközben megjelent európai bírósági ítéletre tekintettel kiegészített változatáról van szó. A mühelykonferencia kiindulópontjainak részletes ismertetésére lásd HARBócz Dorina: Új nemesítési technikák és a génmódosítás jogi nézőpontból. Agrárés Környezetjog, 2018/25, 81-106. Az ombudsmani állásfoglalás pedig elérhető itt: http://www.ajbh.hu/-/ genetikai-modositas-e-a-genszerkesztes-a-jovo-nemzedekek-szoszoloja-az-elovigyazatossag-elverol?inhe ritRedirect $=$ true $\&$ redirect $=\% 2 F(2018$. 02. 26.). 
gam részéről csak a mezőgazdasági alkalmazások felöl, környezetjogászként (azaz alapvetően környezetvédelmi jogi szempontból) közelítem meg a szabályozás által megoldandó problémákat. Ennek során azt állítom középpontba, hogy milyen jelentősége van e tekintetben az elővigyázatosság elvének.

\section{1. Általános (elvi) megfontolások egy szigorú szabályozás mellett}

Mint arra már utaltam, a géntechnológia mezőgazdasági alkalmazása nem homogén szabályozási tárgy. Amikor az a kérdés merül fel, hogy egy technika génmódosítás és eredménye GMO-e, jogi értelemben az a kérdés, hogy a szabályozás hatálya alá esik-e, illetve vonatkoznak-e rá a követelmények, avagy sem. A kérdést bonyolítja, hogy Európában legalább két szabályozási szintröl beszélhetünk: uniós és tagállami jogalkotásról (az alábbiakban tett megállapítások értelemszerüen mindkettőre irányulnak, ugyanakkor csak az európai szabályozásról szólok majd részletesebben).

Hipotézisem az, hogy a génszerkesztés vagy bármilyen új génmanipulációs technika szigorú szabályozása indokolt. Abból indulok ki továbbá, hogy a szabályozás indokai egyrészt magához a technológiához kapcsolódnak, de csak részben függnek annak részleteitől. A szabályozás indokoltsága szempontjából releváns az is, hogy az így előállított új fajták termesztésének és fogyasztásának melyek a hatásai a természetre (más fajokra, a biológiai sokféleségre), az emberi egészségre, felmerülhet-e a génszennyezés veszélye vagy más kockázat, s hogy milyen mindezek tudományos és társadalmi megítélése.

A vita, mint láttuk, több síkon zajlik. Ami a jogtudományi vitát illeti, annak hátteréhez hozzátartozik, hogy a GMO jogi fogalmának értelmezésében nincs teljes konszenzus, tudniillik többen is felvetik, hogy abban vajon inkább a technika vagy inkább az eredmény-e a meghatározó. Azok, akik a technikát (eljárást) állítják középpontba, többnyire a GM-szabályozás hatálya alá tartozónak tekintik az új eljárásokat s eredményüket is. ${ }^{15}$ Ezzel ellentétes következtetésre juthatnak azok, akik csak az új fajtákat (az eredményt) nézik (és azt feltételezik, hogy az új fajták akár természetes úton is létrejöhettek volna). ${ }^{16}$

15 Így Ludwig Krämer, az európai környezetjog egyik legnevesebb szakértője, aki több német termelői érdekvédelmi szervezetnek készített szakvéleményt 2015-ben. KRÄMER, Ludwig: Legal Questions Concerning New Methods for Changing the Genetic Conditions in Plants, https://www.testbiotech.org/node/1342 (2018. 02. 28.). Ugyanerre jutott egy másik német szakértő is a szövetségi természetvédelmi hatóság felkérése alapján SPRANGer, Tade Matthias: Legal Analysis of the Applicability of Directive 2001/18/EC on Genome Editing Technologies. October 2015, https://bfn.de/fileadmin/BfN/agrogentechnik/Dokumente/Legal_analysis_of_ genome_editing_technologies.pdf (2018.02. 28.).

16 A német szövetségi fogyasztóvédelmi és élelmiszer-biztonsági hatóság állásfoglalása: Opinion on the Legal Classification of New Plant Breeding Techniques, in Particular ODM and CRISPR-Cas9. 2017. február, https://www.bvl.bund.de/DE/06_Gentechnik/gentechnik_node.html (2018. 02. 28.). Megjegyzendő, hogy ezzel az állásfoglalással kapcsolatban több szakértő (így Krämer) is kiemelte, hogy a német joghelyzet alapján készült, amely nem felel meg az európai szabályozásnak, s amely ezért az alább említett, Európa-jogi kérdések eldöntése során nem is vehető figyelembe. Egy újabb, árnyaltabb szakmai állásfoglalás is megjelent közben a szakirodalomban (amely a CRISP-eljárásokat 3 kategóriába sorolja - a géntörvény alá nem tar- 
Az én véleményem, hogy figyelembe véve négy körülményt - az érintett eljárások célját, a génmódosítás technikáiban rejlő alapvető hasonlóságokat, az előállított fajták versenyhelyzetét, a velük kapcsolatban megfogalmazott és teljes bizonyossággal el nem oszlatott tudományos kételyeket - ha nem is a szigorúan szabályozott technikákkal és GMO-kal minden részletében azonos, de analóg helyzetről van szó, amelyben eldöntendő jogi kérdés, hogy

a) vonatkozik-e a génszerkesztésre (mint új, idegen gén beültetésével nem járó technikára) a GM-szabályozás követelményrendszere, vagy pedig ha nem, akkor

b) ki kell-e terjeszteni rá annak a hatályát, vagy ha ez sem szükséges, akkor

c) egy a GMO-kra vonatkozótól némileg eltérő szabályozás bevezetése-e az indokolt.

Álláspontom szerint joggazdaságtani, illetve szabályozás-módszertani szempontból nem indokolt a zöld géntechnológiára, a mezőgazdasági termelésre, illetve termékforgalomra vonatkozó joganyagot újabb, speciális szabályozással (például másfajta szempontokkal, eljárásokkal, jogkövetkezményekkel) terhelni. ${ }^{17}$ Ennek rendkívül komoly adminisztrációs igénye lenne. Elegendőnek tünik azt eldönteni, hogy a GMO-kra vonatkozó követelményeket alkalmazni kell-e (ami a hazai szabályozás szintjén az Alaptörvény XX. cikke alapján ítélendő meg), vagy - az uniós szabályozás szintjét vizsgálva - a mutagenezis korábbi technikáihoz hasonló mentesülésröl van-e szó, amelyek közül a magam részéről az előbbi mellett érvelek.

Olyan alternatívát, melyben a génszerkesztésre és eredményére semmilyen, a sajátosságaikat figyelembe vevő szabályozás nem vonatkozik, nem látok. Ezt kívánom alátámasztani a következőkben, általános jogelvek, alapjogi szempontok, illetőleg az elővigyázatosság elve segítségével.

\subsection{A vállalkozáshoz való jog}

Alapjogi megközelítésben mindenekelőtt érdemes hivatkozni a foglalkozás megválasztásának szabadságára (illetőleg vállalkozáshoz való jogra). Amikor az EU a de facto moratórium feloldására kényszerült, azt hangoztatták, hogy miként a biogazdálkodóknak is meg kell adni a jogot arra, hogy GM-mentesen termeljenek, a GM-termelök számára is el kell ismerni a jogot arra, hogy GM-növényeket termesz-

tozó mutagenezis; a törvény hatálya alá tartozó, de nem GMO-t eredményező; valamint a teljes egészében a törvény hatálya alá eső eljárások). THORSTEN, Griebsch: Anwendbarkeit des Gentechnikgesetzes auf nach CRISPR/Cas9 verändertes Saatgut. Natur und Recht, 2018/2, 99.

17 Megjegyzem, ezt ismereteim szerint nem is vetette fel senki érdemben. Igaz, felmerült, hogy a konkrét technikára utaló jelölést a génmérnökség alá sorolt eljárások esetén is fel kellene tüntetni a termékeken, de egy deregulációs elképzelés keretében, amelynek lényege, hogy adminisztratív akadályok helyett a jelöléssel és a nyomon követhetőség biztosításával a fogyasztók döntésére kellene bízni, hogy elfogadják-e az adott eljárást. Az elképzelés hangadója Mark Lynas, aki 2018 januárjában egy oxfordi agrárfórumon lépett fel „kiáltványával", amire Dudits Dénes akadémikus is hivatkozott 2018. 02. 19-i előadásában (lásd a 12. sz. lábjegyzetet), https://www.slu.se/en/Collaborative-Centres-and-Projects/mistra-biotech/from-the-media/2016/ mark-lynas--speech-to-the-oxford-farming-conference-2018/ (2018. 02. 28.). 
szenek. Ez azonban a róka és a tyúk egyenlősége a baromfiudvarban: az eddig termesztésbe vont növények (idegenporzó fajok) példája azt mutatja, hogy nincs békés együttélés, a génmegszökés (génfertőzés) legfeljebb átmenetileg (néhány évig) akadályozható meg. Egy ebből fakadó sarokpont, hogy miként a GMO-kkal kapcsolatban már korábban felmerült (legalábbis Európában), az új génmódosítási eljárások előnyeivel élni nem kívánó - különösen az ökológiai gazdálkodást folytató - termelőknek joguk van ahhoz, hogy „tiszta” szaporítóanyagot kapjanak, termőterületüket genetikai szennyezés ne érhesse. Az új nemesítési eljárásokkal létrehozott fajták kizárása (a GMO-k kizárásához hasonlóan) az ökológiai gazdálkodásból (biotermékekből) az érintett gazdák (és a fogyasztók) jogos szabályozási igénye. (Ez egyébként ágazati szinten értelmezhető gazdasági érdek is egyben, gondolva itt a már említett vetőmagexportra is.) Ez nyilvánvalóan teljes körüen biztosítható akkor, ha a GM-termesztés egyáltalán nem engedélyezett. Arra az esetre, ha mégis termesztésre kerül sor, a koegzisztencia szabályai (pl. izolációs távolságok előírása) érvényesülnek. A tekintetben azonban, hogy ennek a magyar géntörvényböl is ismert megoldása valóban hatékony eszköze-e, nincs tudományos konszenzus ${ }^{18}$ (nehezen állítható tehát, hogy a GM-termeléshez ragaszkodó termelők hasonló jogának biztosítása mellett a nem GM-termelők joga ne sérülhetne).

\subsection{A GM-mentes mezőgazdaság követelménye az Alaptörvényben}

Az Alaptörvény XX. cikke szól a génmódosított szervezetektől mentes mezőgazdaság követelményéröl. Álláspontom szerint, bár ez az alaptörvényi rendelkezés az egészséghez való jognak van alárendelve, annak egyik eszközeként jelenik meg (hogy mennyire alkalmas eszköz erre, az persze kérdés, hiszen az élelmiszerek forgalmazására nyilvánvalóan nem irányul), ${ }^{19}$ emellett önállóan is értelmezhető államcélról van szó, amit az államnak belső intézkedései és külkapcsolatai, például az uniós szabályozás alakításában játszott szerepe körében is szem előtt kell tartania.

18 Álláspontját a koegzisztenciaszabályozás éles kritikájára (miszerint az együttélés legfeljebb pár évig tartható fenn, s elöbb-utóbb bekövetkezik a génfertőzés) építi TANKA Endre: Adalékok a génmódosított növények hazai köztermeszthetőségéhez. Gazdaság és Jog, 2007/3, 21. Lásd még TAHYNÉ KovÁcs: i. m., 240; SzILÁGYI: i. m., 49-50. Szintén szakmai kritikájának ad hangot HESZKY László: A transzgénikus növényfajták termesztésével kapcsolatos tudományos problémák. Magyar Tudomány, 2011/1, 106. További szempont ugyanakkor, ami a hazai megoldás megítélését illeti, hogy a hazai birtokszerkezet sajátosságaiból kifolyólag az előirt 400 méteres izolációs távolság igen szigorú követelmény, s betartása önmagában is ellehetetlenítené a termesztést, mivel csak nehezen (esetenként 50-60 tulajdonossal megállapodva), illetve nagyon drágán lenne megoldható. POPP József-PотоRı Norbert: Élelmiszerár-robbanás és a GM növények korlátozásának gazdasági hatásai az Európai Unióban. In: Dudits Dénes (szerk.): Zöld géntechnológia és agrárinnováció. Barabás Zoltán Biotechnológiai Egyesület, Szeged, 2009, 129; Utóbbi szerzők egy korábbi tanulmányukban egyébként a spanyol tapasztalatokra hivatkozva még azt állították, hogy néhány tízméteres izolációs sáv is elegendő. Popp József-PотоRı Norbert: A GM-növények (elsősorban a kukorica) termesztésének és ipari felhasználásának közgazdasági kérdései Magyarországon. Magyar Tudomány, 2007/4, 451-461. A koegzisztenciaszabályozás alkalmatlanságáról foglal állást HoRvÁTH Gergely: A „zöld” géntechnológia alkalmazásának gazdasági- és agrár-környezetvédelmi kockázatai. Külgazdaság, 2008/7-8, 87-106.

19 Heszky László szerint csak látszólagos az ellentmondás abban, hogy a GM-növények termesztését tiltjuk/ korlátozzuk, míg a GM-termékek forgalomban lehetnek, importálhatók. A mezőgazdaság számára ugyanis a termesztés során felmerülő kockázatok jelentik az igazi problémát. HESzKY (2013): i. m., 65. 
Az MTA állásfoglalásában felvetődött, hogy ha az új (transzgén beültetésével nem járó) technikák eredményét - a géntechnológiai törvény megfelelő alkalmazásával - nem tekintjük GMO-nak, akkor ezen új technikákra az Alaptörvény rendelkezése sem irányadó. Úgy tủnik tehát, mintha az új génmódosítási eljárások természettudományos alapon kivonhatók lennének a követelmények alól. Ezzel kapcsolatban mindenekelött arra emlékeztetek, hogy a kérdés eldöntése továbbra sem a tudósok, hanem a jogalkotó, illetve a jogalkalmazók felelőssége (akiknek persze figyelembe kell venniük a tudományos álláspontokat). Úgy vélem, az MTA feltevése alapjait tekintve is hibás. Az Alaptörvény rendelkezéseinek értelmezésében jelentős szerepe van ugyan a törvényi definícióknak s egyéb törvényi rendelkezéseknek, ${ }^{20}$ de az Alaptörvény szóhasználatának értelmezését nem kötik meg a törvények. (Jó példa erre, hogy a szabályozandó életviszonyok alakulása, esetleges megváltozása alapján változatlan alaptörvényi rendelkezésböl is törvényalkotási kötelezettség fakadhat.) ${ }^{21}$

Sokkal meghatározóbb a kérdés szempontjából, hogy vajon miként alakul az Alaptörvény értékrendje, melyek azok az értékek, amelyeket együtt, egymásra tekintettel kell szem előtt tartania az államnak. Az Alaptörvény P) cikkére figyelemmel - amely a genetikai sokféleség, a honos növény- és állatfajták megőrzésének kötelezettségét állapítja meg - a XX. cikkben említett génmódosított szervezetek körébe a génszerkesztés eredményei is beleértendök, ${ }^{22}$ hiszen a génörökségre mint védett jogtárgyra a termesztés során azok is kockázatot jelentenek, függetlenül attól, hogy a géntörvény is így értelmezendő-e. ${ }^{23}$

Ugyanakkor a XX. cikk szabálya nem kifejezett tilalom, ebböl következően - az időmúlás, a technikákban, megítélésükben bekövetkező változások és a többi alkotmányi érték tükrében való, dinamikus - értelmezése megváltozhat a jövőben. ${ }^{24}$ (Olyan értelmezés azonban nem lehetséges, hogy például a GM-növények termesztése az egészséghez való jog biztosítása érdekében megengedhető - ehhez az Alaptörvényt módosítani kellene. $)^{25}$

20 SZILÁGYI: i. m., 41.

21 A környezetvédelemmel összefüggésben lásd FodoR László: Környezetvédelem az Alkotmányban. Gondolat-DE ÁJK, Budapest, 2006, 39.

22 Mivel az Alaptörvény rendelkezései végső soron a „hagyományos mezőgazdasági kultúra” védelmét biztosítják, azok szellemével ellentétes lenne, ha a GMO-fajtákkal gyakorlatilag ekvivalens genomszerkesztett fajtákat engedélyeznék. TAHYNÉ KovÁcs Ágnes: A jogi szabályozás szükségességét kiváltó tényezőkről a GMO-k kapcsán. lustum, Aequum, Salutare, 2018/2, 187.

23 Ugyanakkor a géntörvénynek is van olyan értelmezése, amelyik szerint annak eltérése az Alaptörvénytől fennáll, és épp abban, hogy míg az Alaptörvény és az uniós jog megfogalmazása is inkább az eredmény, addig a törvény a technológia felöl közelít („géntechnológiával módosított”), s a génszerkesztés kétségtelenül géntechnológia. Lásd Darvas Béla publicisztikáját az Élet és Tudomány 2018. 07. 20-ai számában „A miniszter brácsázik” címmel, https://www.es.hu/cikk/2018-07-20/darvas-bela/a-miniszter-bracsazik.html (2018. 07. 27.).

24 Heszky például arra utal, hogy egyszer akár igazi fejlődést jelentő, mindennemű egészségi és környezeti kockázattól mentes, a társadalom számára elfogadható alkalmazása is elképzelhető a GMO-knak, s ebben az esetben a mostani szabályozás már nem tartható fenn tovább. HESZKY (2013): i. m., 66.

25 Ez a kérdés nem is olyan egyszerü, tekintve, hogy van példa arra (a feltételezhetően rákkeltő akrilamid keletkezésétől mentesen süthető Innate burgonya), hogy a génmódosítás az emberi egészség megőrzését szolgálhatja. Az említett fajta egyébként az USA-ban már évek óta termeszthető, http://zoldbiotech.hu/cikk/256Az-USDA-enged-lyezi-a-m-dos-tott-burgony-t-Most-m-r-a-s-ltkrumplikedvel-k-n-a-sor (2018. 08. 27.). 
Egyébként az egész kérdésfelvetés nagyon hasonlónak tủnik ahhoz, ami az uniós jog értelmezése körében is felmerült (lásd alább a C-528/16. sz. üggyel kapcsolatban írtakat). A hazai szabályozási helyzet azonban egész más, mint az európai (hisz az uniós jog fö szabálya az engedélyhez kötöttség, a hazaié pedig a tiltás, hátterében egy - több szempontból vitatható, ${ }^{26}$ de szélesen értelmezhető - alaptörvényi elöírással). A magyar alaptörvényi rendelkezés értelmezését erősítheti az EU Bíróságának döntése, miszerint GMO-nak minősül a génszerkesztés eredménye. Egy ellentétes döntés azonban véleményem szerint nem lenne mérvadó. (Ha netán azt mondta volna ki a bíróság, hogy a génszerkesztés eredménye nem GMO, az nem eredményezte volna, hogy hazánkban a génszerkesztés szabad utat kap. Az Alaptörvény nem is az uniós jog átültetését szolgáló jogi aktus. Elfogadásakor egyébként az uniós joggal koncepcionális ellentétben is állt. ${ }^{27}$ Csak az elfogadását követően, 2015-től változott az uniós jog úgy, hogy elismerte a tagállamok nagyobb mozgásterét. $)^{28}$

\subsection{Az elővigyázatosság elvéröl általában}

Fontos érv lehet az elővigyázatosság alapelve, amelynek a meghatározó jelentősége ezen a jogterületen vitán felül áll, legalábbis Európában. Magának a GMszabályozásnak az elemeit is áthatja az elv (például az engedélyezésnek része a kockázatok értékelése, az engedélyek felülvizsgálhatók, az engedélyezett fajtákkal szemben is intézkedések hozhatók stb.). Emellett a teljes elutasítás is értelmezhető az elővigyázatosság megnyilvánulásaként.

A mostani konkrét kérdésben is több szinten értelmezendő az elv, hiszen uniós és nemzeti jogalkotási, illetve jogalkalmazási döntésekröl is szó van. A jogalkotónak kell a döntést meghoznia (génmódosítás-e a génszerkesztés?), illetve a jogalkotó korábbi döntése adott esetben külön értelmezést igényel (amire szemléletes példa az alább említendő jogeset). Mindkét szinten úgy értelmezendő az elv, hogy a bizo-

${ }^{26}$ Az érintett alaptörvényi rendelkezés megfogalmazása (nem egyedül) eltér a tételesjogi fogalomhasználattól, aminek egyik magyarázata a rendelkezés szimbolikus volta, jelzésértéke lehet, a szóhasználatból ugyanakkor bizonytalanságok is fakadnak. Lásd SzILÁGYI-TótH: i. m., 483; Fodor László: A természeti tárgyak helye és szerepe az új alkotmányban. In: Drinóczi Tímea-Jakab András (szerk.): Alkotmányozás Magyarországon 2010-2011, I. kötet. Pázmány Press, Budapest-Pécs, 2013, 98-100.

27 Megjegyzendő, hogy az Alaptörvény tervezetére vonatkozóan volt olyan módosító javaslat, amely a GMOmentes, egészséges élelmiszerek követelményét tartalmazta, de ez nyíltan sértette volna az európai jogot (az áruk szabad áramlásának követelményére tekintettel), ezért változtatták génmódosított szervezetektöl mentes mezögazdaságra a szöveget. T. KovÁcs Júlia: A GMO-mentes Alaptörvény hatása a mezögazdaságra - különös tekintettel a visszaszerzett EU-tagállami szuverenitásra és a TTIP-re. In: Szalma József (szerk.): A magyar tudomány napja a Délvidéken 2014. Újvidék, VMTT, 2015, 308-309; SzILÁGYI János EdeRAIsz Anikó-Kocsıs Bianka Enikő: A magyar agrárjog legújabb fejlődési irányai az élelmiszer-szuverenitás szempontjából. Agrár- és Környezetjog, 2017/22, 190.

${ }_{28}$ Fodor (2013): i. m, 98-100.; Az Európai Parlament és a Tanács (EU) 2015/412 irányelve (2015. március 11.) a 2001/18/EK irányelvnek a tagállamok számára a géntechnológiával módosított szervezetek (GMO-k) területükön történő termesztésének korlátozására, illetve megtiltására biztosított lehetőség tekintetében történő módosításáról. 
nyítási kötelezettség az új technológia alkalmazóját (a kérelmezőt) terheli, illetve a nem bizonyítható, de (az engedélyezés szempontjából) releváns körülményeket a kérelmező terhére kell értékelni. Ha egy döntés már megszületett, az utóbb vitatható, illetve felülvizsgálatra szorulhat, ami bizonyos értelemben ellenbizonyítást igényel.

A jogalkotónak az uralkodó tudományos állásponton túl a kisebbségi véleményeket is figyelembe kell vennie. A biztonsági követelményeket pedig nem csupán a technika lehetőségeihez, hanem „a tudomány és a technika mindenkori állásához” kell igazítania, vagyis azt a legszigorúbb védelmet kell garantálnia, amit a tudományos felismerések megkívánnak (ha pedig nincs megfelelö megoldás a kockázatok kezelésére, az engedély pusztán ezen az alapon is megtagadható; azaz további kutatások és újabb bizonyítékok szükségesek a veszélytelenséggel kapcsolatban, a jogi szabályozás megváltoztatásának követelése helyett). ${ }^{29}$

\subsection{A tudomány szerepe (gondolatok az MTA állásfoglalása ürügyén)}

Tudományos szempontok is szerepet játszanak, természetesen. Erre vonatkozóan most csak az MTA 2017 decemberében kiadott, s a tanulmány bevezetőjében már említett állásfoglalását idézem fel, hiszen ez kíván új információt szolgáltatni a jogi vitához: ne tekintsük GMO-nak a precíziós nemesítés eredményét, ha abban nincs idegen gén. Az állásfoglalás „észszerübb, a genomszerkesztési módszerek valódi lehetőségeihez és kockázataihoz igazodó szabályozást" sürget, hivatkozva az Európai Akadémiák Tudományos Tanácsadó Testülete (EASAC) által néhány hónapja kiadott, az EU döntéshozóinak szóló állásfoglalására. ${ }^{30}$

Az MTA-állásfoglalás - az elővigyázatosság elve kapcsán elmondottak tükrében - úgy tűnik, hogy az „uralkodó” vagy többségi tudományos álláspont igényével kíván fellépni. A természet-, illetve élettudományi vitában a magam részéről állást foglalni nem tudok (itt rajzolódnak ki legerőteljesebben a jog és a jogtudomány korlátai), ugyanakkor arra vonatkozóan, hogy az állásfoglalás a jogi szabályozással kapcsolatban értelmezhetö-e, néhány szempontra fel kell hívnom a figyelmet. (Az állásfoglalás egyébként egy dokumentumba foglalva jelent meg egy egyoldalas bevezetövel. A két rész között több kisebb, hangsúlybeli különbség látható.)

Mindenekelőtt az állásfoglalás több helyen is tetten érhető, korrekt megfogalmazása érdemel figyelmet, amely az elővigyázatosság elvének teret hagy. Feltételes módban fogalmazza meg ugyanis, hogy „a precíziós nemesítés alapvetően különbözhet a genetikailag módosított organizmusok (GMO) létrehozásától". Az állásfoglalás a fö különbséget az idegen gének nélküli manipuláció lehetőségében látja, anélkül, hogy részletezné a kockázatokban, következményekben rejlő különbsége-

29 Az elővigyázatosság elvének e „tankönyvbe illő” értelmezését a német atomenergia-szabályozásban találhatjuk meg. Lásd FODOR László: Klímavédelem az energiajogban - szabályozási modellek Németországból. Wolters Kluwer Complex, Budapest, 2014, 73-74.

30 Science Advice for the Benefit of Europe Genome Editing: Scientific Opportunities, Public Interests and Policy Options in the European Union. European Academies Science Advisory Council, Halle, 2017, 27, https:// www.easac.eu/fileadmin/PDF_s/reports_statements/Genome_Editing/EASAC_Report_31_on_Genome_ Editing.pdf (2018. 03. 02.). 
ket, amelyek ebből fakadhatnak. Egy másik megállapítás szerint „a megtervezett DNS-módosítás a természetben is lejátszódó folyamatokhoz hasonlóan valósítható meg, a korábbiaknál sokkal precízebben, ezzel is csökkentve a nem kívánt hatások kockázatát”. Nem állítja tehát, hogy a kockázatok teljes körüen kizárhatók lennének.

Csak egyetérteni lehet azzal a további megállapítással, hogy jelentős tudományos felfedezésről van szó, amit legalábbis a tudomány síkján támogatni kell, ahogy bizonnyal az orvosi alkalmazás körében is. Ugyanakkor az állásfoglalás több helyen is azt sugalmazza, hogy a vitás kérdések már nem jelentősek, a genomszerkesztés eloszlatott minden, a GMO-kkal kapcsolatos kétséget, ami azonban nincs így. ${ }^{31}$ Például már a címben „Az élhetőbb világért” kitétel szerepel, a bevezető érvelésében pedig a mezőgazdasági alkalmazás egyébként erősen vitatható ${ }^{32}$ és az orvosi alkalmazás részben elvitathatatlan előnyei egymás mellett szerepelnek. (Utóbbi kapcsán úgy vélem, hogy nem szerencsés a mezőgazdasági alkalmazással egy lapon említeni az orvosi alkalmazást, hiszen az orvosi alkalmazás általában nem támaszthatja alá a mezőgazdaságit. Magában a szűkebb állásfoglalásban, ahol nyilván több hely volt a kifejtésére, már tiszták az összefüggések. Megjegyzem ugyanakkor, hogy az új technikák orvosi alkalmazása kapcsán - ha lehet - még fokozottabb elővigyázatosság indokolt, amit egyes frissen publikált tudományos eredmények is aláhúznak, utalva a nem várt/nem tervezett genetikai változás kockázatára.) ${ }^{33}$

\subsection{A szabályozás „lassúságának” előnye (gondolatok az MTA állásfoglalása ürügyén)}

Aligha vitatható megállapítás az MTA állásfoglalásában, mely szerint „[a] genomszerkesztés esetében talán minden korábbinál markánsabban látható, hogy a törvényhozás nem képes lépést tartani a technológiai fejlődéssel”. Hiszen az új technikák arra irányítják a figyelmünket, hogy a jelenlegi előírások egyre nehezebben érvényesíthetők, a géntechnológia rohamos fejlődése miatt. A szabályozást időről időre érdemes tehát felülvizsgálni.

Ebből azonban nem következik az is, mint az állásfoglalás sugallja, hogy az új technikákat engedélyezni (mentesíteni) kell (ahogyan az sem, hogy a jogi szabályozás „lemaradása” a konkrét kérdésben bizonyított lenne). Emellett tudomásul kell venni, hogy a jog reflexív jellegéből fakadóan a szabályozási folyamat lassúsága

31 Lásd a European Network of Scientists for Social and Environmental Responsibility (ENSSER) állásfoglalását (2013. október 21.). Magyar nyelven: Nincs tudományos konszenzus a GMO-k biztonságosságát illetően. Biokontroll, 2013/3-4, 73-79.

32 Gondolok itt például a nem szelektív gyomirtó szerek alkalmazására, amit az azoknak ellenálló fajták nemesítése elősegít, illetve a rezisztens kártevők megjelenésére, ami előbb-utóbb szükségszerüen követi a GM-növények bevezetését.

33 „Azt találtuk, hogy a DNS-ben végbement változásokat korábban súlyosan alábecsülték” - szerepel egy tanulmányban a CRISPR/Cas9 technológia kapcsán. KosıCKI, Michael-TomBERG, Kärt-BRADLEY, Allan: Repair of Double-Strand Breaks Induced by CRISPR-Cas9 Leads to Large Deletions and Complex Rearrangements. Nature Biotechnology, online: 2018. július 16., https://www.nature.com/articles/nbt.4192.pdf (2018. 07. 27.). A technológia és a humán alkalmazás egyes alapjogi, illetve bioetikai kérdéseire lásd ZELLER Judit: Lombikban a jövőnk - terápia vagy tökéletesítés? Fundamentum, 2017/3, 15-28. 
bizonyos mértékig természetes. ${ }^{34} \mathrm{~A}$ jogalkotás szempontjaihoz az ilyen és hasonló esetekben hozzájárul az elővigyázatosság követelménye, a körültekintés pedig időt igényel. A pontosan nem ismert kockázatok megengedésével Pandora szelencéjét nyitjuk ki, hiszen utána esetleg már nem vagyunk képesek megállítani a beindult folyamatokat.

Való igaz az is, hogy az európai jogalkotás még ehhez képest is viszonylag lassú, ami azonban nem pusztán a felesleges bürokrácia eredménye, hanem a folyamat többszereplős, demokratikus, kompromisszumos természetéből is fakad. A jogalkotás folyamata sokszor valóban csekély hatékonyságú - például a világpiaci versenyben valóban hátrányt jelenthet gazdasági szereplőknek -, ugyanakkor ne feledjük, hogy ennek a lassúságnak vannak elönyei is; nem feltétlenül pénzben kifejezhetöen, például ilyen lehet a legitimáció, a bizalom megörzése a társadalom szélesebb körében, vagy veszélyekkel is járó tevékenységek esetén bizonyos konfliktusok elkerülése.

\subsection{A diszkrimináció tilalma}

Az MTA állásfoglalása nyomán felvethető egy további alapjogi kérdés, mégpedig hogy vajon nem valósul-e meg diszkrimináció azzal, ha az idegen gén beültetésével nem járó mutagenezist és a transzgenezist ugyanúgy kezeljük (illetöleg - az alább részletesebben érintendő uniós szabályozásban - nem diszkrimináció-e, ha az irányelv szerint a követelmények alól mentesülö mutagenezist és a célzott mutagenezist nem egyformán kezeljük?). Az MTA által megfogalmazott igény jogi nyelvre ültetve azt jelenti, hogy az idegen gén jelenléte, illetőleg hiánya olyan lényegi különbség a szabályozási tárgyak (transzgenezis - mutagenezis) között, amely eltérő szabályozásukat indokolja.

Ezzel kapcsolatban úgy vélem, hogy a kérdés részben valóban tudományos. Amit a tudomány megállapít, azt a jogalkotónak és a jogalkalmazónak is figyelembe kell vennie. Ennek azonban vannak korlátai, mivel a jog autonóm szabályrendszer, ami azt jelenti, hogy nem képes, de nem is köteles a természettudományok, élettudományok stb. mechanikus követésére (megvannak a maga dogmatikai, rendszertani és módszertani sajátosságai). ${ }^{35}$ Ráadásul más szempontokat (például társadalom- és gazdaságpolitikai szempontokat és igényeket s több tudományterület eredményeit) is érvényesítenie kell.

34 Miként a korábban már említett mühelykonferencián többen is megfogalmazták, a szabályozási gyakorlatban az elővigyázatosság elve „nem áll nyerésre”. Számos negatív, múltbeli példa hozható fel arra, hogy a jogi szabályozás csak akkor állított korlátokat egy-egy tevékenység, technológia elé, amikor már az emberiség megtapasztalta az általa okozott szenvedést (például az atomfegyverek).

35 A jog autonóm szabályozórendszer, s nem alkalmazkodik mechanikusan a természettudományok felismeréseihez, fogalmi rendszeréhez. Figyelembe veszi azokat, de más szempontokat is, mint például saját fogalmi rendszerét és definiálási módszereit, illetve más (például gazdasági, társadalompolitikai) érdekeket, az emberi észlelés korlátait vagy a szokásokat is. Másrészt tudjuk, hogy a természettudományos ismereteknek is vannak korlátai, s bizonyosan vannak olyan természeti jelenségek, amelyek még felfedezésre várnak. Ez is indokolja az elővigyázatosságot a jogalkotó részéről. Fodor (2014): i. m., 14. 
A diszkrimináció kérdése azonban elsősorban a szabályozási tárgy mibenlétén múlik. Álláspontom szerint itt a szabályozási tárgy nemcsak két vagy több technológia önmagában, illetve nem is a GM-termék önmagában, hanem a velük kapcsolatos életviszonyok egy bizonyos köre (például a nemesítésen túl a köztermesztésbe vonás, forgalmazás is; a GM-szabályozásban ezekre is vonatkoznak az engedélyezési, termékjelölési, koegzisztencia- és egyéb követelmények). Vagyis a fő kérdés megválaszolásakor komplex megközelítés indokolt. A GMO-kra vonatkozó követelmények alkalmazásához nem szükséges, hogy a genomszerkesztés teljes technológiai azonossága fennálljon, de még az sem, hogy részleteiben pont ugyanazok legyenek az esetleges kockázatok. Ha csak a technikák egyes részleteit nézzük, jelentősnek tűnik a fejlődés, de ha az alkalmazásra, fogyasztásra, társadalmi elfogadottságra stb. is gondolunk, már jóval kevesebb különbség látszik. Innen nézve ráadásul úgy tünik, hogy az új genomszerkesztési technikák mezőgazdasági alkalmazása mellett szóló mai érvek sem különböznek érdemben a génmódosítás mellett megfogalmazott, immár több évtizedes érvektől (miért ne alkalmaznánk tehát a GMO-kkal kapcsolatban egykor érvényesített elővigyázatosságot ma, a genomszerkesztés újnak hívott technikáira?).

A diszkrimináció kérdéséhez kapcsolom még a társadalmi elfogadottság, megítélés szerepét. Jelentős lehet ugyanis a közvélemény szerepe, amire az MTA-állásfoglalás is apellál olyanformán, hogy szükségesnek tartja annak formálását (társadalmi vita, oktatás útján). Nyilvánvaló, hogy a genomszerkesztés egyes alkalmazásainak egyértelmü társadalmi elfogadottsága legitimálhatja az MTA-állásfoglalásban körülírt szabályozási megoldást. Ugyanakkor azt a magam részéről kétségesnek látom, hogy vajon a lakosság, az átlagos ismerettel és tudatossággal rendelkező fogyasztók számára lehetséges-e (a szó legnemesebb értelmében vett, tisztán ismeretterjesztő eszközökkel) közvetíteni a célzott mutagenezis és a transzgenezis közti különbséget.

\section{A C-528/16 ügyben tett fötanácsnoki indítvány kritikája}

Az Európai Bíróság előtt 2018. július 25-én született ítélet egy előzetes döntéshozatali eljárásban, amely a francia Államtanács kezdeményezésére indult. Ennek az ügynek a tétje szintén az volt, hogy vajon az új génszerkesztési eljárásokra a GMkövetelmények irányadók-e, ugyanakkor az általam eddig alkalmazottól némileg más megközelítésben merült fel a probléma. Franciaországban ugyanis már született egy megengedő, azaz a szigorú GM-követelményektöl eltekintő döntés, amelyet egyes termelői, illetve természetvédő szervezetek megtámadtak, s mivel az ügyben az uniós jog érvényességének a kérdése is felmerült (ui. a vonatkozó francia törvény mögött részben az uniós irányelv áll), a nemzeti bírói fórum az EU Bíróságához fordult. Az ügyben szükség volt az uniós jog értelmezésére, ami egyébként valójában nem is egy, hanem több uniós jogszabály értelmezését jelentette.

Négy, a következő pontokban megvilágított kérdést tett fel a nemzeti bíróság, amelyek leegyszerüsítve a következők:

1. Vajon a mutagenezis révén elóállított szervezetek GMO-nak minősülnek-e, illetve a 2001/18/EK sz. GMO-irányelv a hatálya alól a mutagenezis valamennyi eljárá- 
sát (vagy csak a hagyományosan alkalmazott, bizonyítottan biztonságos) eljárásait mentesíti-e?

2. Mentesülnek-e a mutagenezissel elöállított fajták a közösségi fajtajegyzékröl szóló 2002/53/EK irányelv követelményei alól?

3. Vajon a GMO-irányelv teljes harmonizációra irányul-e, azaz van-e a tagállamoknak hatáskörük a mutagenezissel elöállított fajták szabályozására?

4. Érvényesnek tekinthető-e az irányelv hatálya alóli mentesülésre vonatkozó szabály, tekintettel a technológiák fejlődésére? (E kérdésnek csak az első kérdés függvényében van értelme: ha ti. az irányelv hatálya a génszerkesztésre nem terjedne ki.)

A Bíróság fötanácsnoka 2018. 01. 18-án hozta nyilvánosságra indítványát az ügyben. ${ }^{36} \mathrm{Ez}$ az uniós másodlagos jogot az elsődleges jog alapján, de úgymond „dinamikusan" értelmezi, vagyis az uniós jog érvényességének kérdését a szabályozási helyzet - időmúlás, technológiák fejlödése - megváltozása tükrében is felveti. ${ }^{37}$ Tudvalévő, hogy az Európai Unió Bírósága gyakran követi az igen részletes és alaposan indokolt, tudományos igényességű főtanácsnoki indítványban foglaltakat, ${ }^{38}$ jelen esetben azonban a Bíróság a fötanácsnoki indítvánnyal ellentétes döntésre jutott, s mindössze egy pontban fejezte ki egyetértését (ezt is alighanem gesztusértékűnek tekinthetjük). Az indítványt ennek ellenére (a francia vonatkozásoktól függetlenül is) érdemes megvizsgálni. Az ítélet ugyanis a GM-pártiak és GM-szkeptikusok (ellenzők) küzdelmében egy rendkívül fontos csatát döntött el, de a fötanácsnoki érvelés egyes elemei még vissza fognak köszönni a jövőben. Ha nem az Európa-jog, akkor a nemzetközi jog szintjén. Talán az is elfogadható érv lehet, hogy az indítványban foglaltak elemzése további lehetőséget kínál számomra az elővigyázatosság elvének az értelmezésére, a szakirodalomban eddig elhanyagolt szempontok alapján.

\subsection{A mentesítés hatályának és okának összefüggése}

A terjedelmes indítvány a következő joghelyzetet tárta fel. Az EUMSZ 191. cikke a környezetpolitika vonatkozásában a védelem magas szintjéböl és az elövigyázatosság elvéböl indul ki. A szakterület másodlagos jogforrása a 2001/18/EK irányelv, amely a GMO-k alkalmazásához engedélyezési, nyomonkövetési, címkézési és egyéb követelményeket kapcsol. (Ehhez társul még - többek közt - a fajtajegyzékről szóló 2002/53/EK irányelv ${ }^{39}$ követelményrendszere, amely utal a 2001/18/EK irányelvben is elöírt intézkedések szükségességére, s kimondja, hogy a GMO-k elismerésére vonatkozóan sajátos előírásokat kell érvényesíteni, ugyanakkor rögzíti, hogy

36 Michel Bobek főtanácsnok indítványa; Confédération paysanne és társai, C-528/16. sz. ügy. ECLI:EU:C:2018:20.

37 A keresetet benyújtó francia parasztszövetség szerint a mutagenezis technikái jelentősen fejlődtek azóta, hogy kivételezett jellegüket a francia környezetvédelmi törvény megállapította. Ez a fejlődés azonban nem aggálymentes. Azóta mutagenezissel is előállíthatók vegyszerrezisztens (a konkrét esetben: repce-) fajták, amelyek használata jelentős kockázatokkal jár (véletlen mutagenezis - célzott mutagenezis).

38 VÁrnay Ernö-Papp Mónika: Az Európai Unió joga. Wolters Kluwer, Budapest, 2016, 132.

39 A Tanács 2002/53/EK irányelve (2002. június 13.) a mezögazdasági növényfajok közös fajtajegyzékéröl (HL L 193, 2002. 07. 20., o. 0001-0011). 
a jegyzékben szereplő fajták vetőmagjai az EU-n belül szabadon forgalmazhatók.) Az irányelv preambuluma hangsúlyozza, hogy a szabályozás előkészítése során az elővigyázatosság elvét figyelembe vették, s a végrehajtás során is érvényesíteni kell ezt az elvet. ${ }^{40}$

Ugyanakkor maga az irányelv az egyébként GMO-nak tekintendő szervezetek egy bizonyos körét mentesíti a hatálya alól (3. cikk; I/B. melléklet). Ezt a kört egyfelöl két technika megnevezésével, másfelöl azokra vonatkozóan egy feltétel rögzítésével vonja meg: 1. a mutagenezis és a növényi sejtfúzió mentesül, ${ }^{41} 2$. feltéve, hogy más eljárásból származó örökítőanyag alkalmazására nem kerül sor (kizárólagosság - az irányelvet idézve: „...feltéve hogy azok nem foglalják magukban olyan rekombináns nukleinsav molekulák vagy géntechnológiával módosított szervezetek felhasználását, amelyek mások, mint a [...] felsorolt technikák/módszerek".)

Az irányelv preambuluma (17. bekezdés) szerint vannak olyan eljárások, amelyeket hagyományosan használnak, s amelyek biztonságosnak tekintendők. Ezekre nézve az irányelvet nem kell alkalmazni. Az indítvány e preambulumbekezdést a mentesítési előírásra vonatkoztatja, s kettejük viszonyát úgy ragadja meg (a keresetlevélben foglaltak cáfolatára), hogy a preambulum nem magyarázata a mentesítő előírásnak, vagyis nem lehet a normaszöveget úgy értelmezni, hogy az csak a már hagyományosan használt eljárásokat mentesítené. Többek közt azzal indokolja ezt, hogy a 17. preambulumbekezdés előbb került a hatályos normaszövegbe, mint a mutagenezis mentesítése.

Az okfejtéssel nem értek egyet. Bár a két szöveghely valóban nem utal (például szóismétléssel) egymásra, nonszensznek tekintem az állítást, miszerint a preambulum ne a jogalkotáskor figyelembe vett szempontokat, indokokat, célokat és elveket tartalmazná. Igaz, hogy az érintett szöveghely már a hatályos irányelv elődjében, a 90/220/EGK irányelvben is benne volt, de ez csak azt jelenti, hogy a jogalkotó az új irányelv elfogadásakor figyelembe kívánta venni a korábban is leírt szempontot, tehát az evidensen hozzátartozik a vonatkozó norma értelmezéséhez.

\subsection{A génmódosítás irányelvi fogalma és az új technikák besorolásának lehetőségei}

Az indítvány rámutat, hogy a GMO fogalmának irányelvi meghatározása nem tartalmazza a transzgenezist differentia specificaként. A definíció lényege: „....a genetikai anyagot olyan módon változtatták meg, amely nem fordulna elő a természetben

40 Ez a megfogalmazás (szórend) jelentőséggel bír, ugyanis nem egyszerűen azt jelenti, hogy a jogalkotó tiszteletben tartotta az elvet, hanem azt, hogy a szükséges és lehetséges mértékben - a döntéskor adott ismereteket hasznosítva - érvényesítette is. A bírói gyakorlat ismeretében ez azt sugallja, hogy pusztán az elővigyázatosság elvére való hivatkozással nem vitatható a szabályozás érvényessége, illetve nincs mód korlátozó, tagállami intézkedésre sem. (Erre a kérdésre még visszatérek.)

41 Megjegyzem, hogy az indítvány nem idézi az irányelv szövegét, hanem csak példálózó jelleggel emeli ki abból a mutagenezist. A normaszöveg ismeretének hiányában ez félreérthető, mert a kivételek tág értelmezésének lehetőségét sugallja. Az indítvány sokszor egyébként is nehezen követhető, nemcsak a fogalmazás pongyolaságai, hanem a gondolatmenet bonyolultsága miatt is. 
párosodás, illetve természetes rekombináció útján". Emellett bizonyos technikák példálózó (!) felsorolása szerepel az irányelvben, amelyek a hatálya alá tartoznak (pozitív lista, I/A melléklet 1. rész), s néhány olyan is, amelyik (szintén a kizárólagosság követelményének teljesülése mellett, ti. transzgén nélkül) nem tartozik ide, azaz nem tekintendő az irányelv hatálya alá eső génmódosításnak (negatív lista, taxatív, I/A melléklet 2. rész). ${ }^{42}$ Ennek alapján elmondható, hogy a GMO jogi fogalmának nem eleme a transzgenezis, de az a nyitott definícióba beleérthető, különös tekintettel a felsorolt eljárásokra (pozitív lista), amelyek a transzgenezisre utalnak. Ebböl a meghatározásból ugyanakkor az következik, hogy GMO-nak minősülhet olyan szervezet is, amelynek létrehozása során nem került sor transzgenezisre.

Mindezek alapján valójában nem két, hanem három lehetőség adódik, amikor valamilyen jogi kategóriába kell sorolni egy génsebészeti úton módosított szervezetet: 1. GMO, amelyre vonatkozik a szabályozás; 2 . GMO, amelyre nem vonatkozik a szabályozás (mentesülés); 3. nem GMO. (Ezen hármas besorolásnak persze csak elvi, vagy ha úgy tetszik, dogmatikai jelentősége van, és sem a főtanácsnok, sem a Bíróság nem tette magáévá. )

Ha transzgenezisröl (is) van szó, alapvetően csak a GMO-kategória jön szóba. Ebböl azonban nem feltétlenül következik, hogy a mutagenezis eredménye ne lenne GMO. A mutagenezis eredménye - ha az irányelvi GMO-definícióba nem illik bele - EU-jogi értelemben nem GMO. Ha beleillik, akkor viszont GMO, s - az említett feltételektől függően - kiterjed rá az irányelv hatálya.

\subsection{A dinamikus értelmezés igénye és az elövigyázatosság}

A konkrét ügyben nem a mentesülés feltételeinek az értelmezése volt vitatott, hanem az, hogy vajon a szabályozás óta megjelent új technikák kockázataira kiterjedt-e az az elövigyázatosság, ami a jogalkotót a régi technikák ismeretében hozott döntésekor, 2001-ben vezette. Azaz: amikor a hatályos szabályt a jogalkotó megfogalmazta, mérlegelte-e annak lehetőségét, hogy az érintett technikák fejlődhetnek? Ha igen, akkor nincs új szabályozási helyzet; ha nem, akkor viszont van.

A főtanácsnok ennek megvilágítására belebocsátkozott az elővigyázatosság elvének értelmezésébe. Látszólag nem is akárhogy, hanem az indítvány megfelelö alcíméből kiolvashatóan - „Az elővigyázatosság elve az uniós jogban” - egy általános,

42 1. rész: „DNS rekombinációs technikák, amelyek magukban foglalják a genetikai anyag új kombinációinak létrehozását olyan nukleinsav molekulák beépítésével vírusba, bakteriális plazmidba vagy egyéb hordozóba, amelyeket bármilyen módon egy szervezeten kívül hoztak létre, és azok beépítését egy gazdaszervezetbe, amelyben azok természetes körülmények között nem fordulnak elö, de amelyekben azok képesek a folyamatos reprodukcióra; (2) Olyan eljárások, amelyekkel a mikroorganizmuson kívül elöállított örökítő anyagot juttatják a mikroorganizmusba, ideértve a mikroinjektálást, makroinjektálást és mikroenkapszulációt; (3) sejtfúziós (beleértve a protoplaszt fúziót) és hibridizációs eljárások, amelyekkel két vagy több sejt fúziója által, természetes körülmények közt elő nem forduló módszereket alkalmazva, örökölhető génállomány új kombinációjával rendelkező élő sejtet hoznak létre.” 2. rész: „in vitro megtermékenyítés, (2) természetes folyamatok, mint például: konjugáció, transzdukció, transzformáció, (3) poliploid indukció." Az indítvány 83. pontja egyébként arra jut, hogy utóbbiak is GMO-t eredményeznek abban az esetben, ha rekombináns nukleinsav molekulák használatával járnak. 
vagyis a konkrét értelmezési helyzettől független megközelítés igényével. Elemzésének a lényege, hogy az elővigyázatosság akkor alapoz meg valamely - ideiglenes tagállami, bizottsági - intézkedést, ha a kockázat nem puszta feltételezésen, hanem (átfogó, az ügyhöz mért) kockázatelemzésen alapul: „...Legyen legalább néhány, tudományosan megalapozott, észlelhető kockázat." Emellett az indítvány kiemeli, hogy az állandó szabályozáshoz képest az ideiglenes intézkedések megalapozásához a kockázatok valószínűsítésének kisebb foka is elégséges.

A főtanácsnok érvelése álláspontom szerint egyoldalú, mivel kizárólag egy olyan jogalkalmazói megközelítésen alapul, amelynek alkalmazására mindig az unióstól eltérő tagállami intézkedések értékelése körében került sor, amikor ti. az uniós és a tagállami jog viszonyára vonatkozóan, a fő szabály alóli kivétel alátámasztásáról volt szó, amit mindig szigorúan kell értelmezni. ${ }^{43}$ Ebben az értelmezési tartományban (az egyöntetü bírói gyakorlat szerint) szigorúbb tagállami intézkedést olyan körülmény nem alapozhat meg, amelyet az uniós jogalkotó már megfelelően értékelt. Az elővigyázatosság azonban szerintem nem körülmény vagy szempont (azt hiba volna ekként kezelni), hanem a szempontok, körülmények (például milyen technikák ismeretesek, s azoknak milyen a megítélése?) mérlegelésének a meghatározó elve, amit az irányelv végrehajtása során is érvényesíteni kell.

Jelen ügyben azonban szerintem ez a megközelítés csak mellékszál kellett volna, hogy legyen, mivel a fő kérdés arról szólt, hogy az uniós irányelvet hogyan kell értelmezni, alkalmazni a mutagenezis új eljárásaira. Ennek eldöntésétől függően merülhet fel, hogy lehetséges-e (eltérő, kiegészítő vagy szigorúbb) tagállami intézkedés, illetve a módosítás igénye (ami már természetesen nem a bíróság hatásköre).

A fötanácsnok a mutagenezis fogalmi körének értelmezése körében is visszatért az elővigyázatosságra, ahol megint csak nem tudok vele egyetérteni. Úgy álítja be, mintha az elővigyázatosság a korábban elfogadott jogszabály mai viszonyoknak megfelelő (dinamikus) értelmezésének jelentené az akadályát (ti. akkor, ha az elővigyázatossággal akarjuk alátámasztani, hogy a mutagenezis fogalmába eső, de korábban ki nem próbált, s biztonságosnak nem tekintett technológiákra a követelmények alóli mentesítés ne vonatkozzon). Úgy vélem, hogy itt a jogtechnikai megoldás került előtérbe az érdemi kérdés helyett (az érdemi kérdés az, hogy mi az elővigyázatosság tartalma? szabad-e ezeket a szervezeteket engedélyezés és egyéb előírások nélkül előállítani és kibocsátani?). Az alapügyben a felperesek éppen hogy a dinamikus értelmezés mellett kardoskodtak (csak épp a másik oldalról közelítették azt meg, s ezért a főtanácsnoktól eltérő következtetésre jutottak).

43 Egyet kell ugyan érteni a főtanácsnokkal, hogy a szakirodalmi álláspontokhoz képest az elővigyázatosság bírói értelmezése indokoltan „sokkal körülhatároltabb és talán még óvatosabb” is, de nem mindegy, milyen helyzetre alkalmazzuk. Való igaz, hogy a szakirodalom is föként ilyen ügyek (ideiglenes tagállami vagy bizottsági intézkedések jogszerüsége) alapján mutatja be az elv értelmezését, így BÁnDı Gyula és szerzőtársai: Az Európai Bíróság környezetjogi itélkezési gyakorlata. Szent István Társulat, Budapest, 2008, 105-111. De volt már más típusú konfliktus is (például érzékeny területek kijelölését előíró, uniós irányelv hiányos tagállami végrehajtása miatt a C-280/02. sz. ügyben; uniós irányelv érvényességének kérdése a C-343/09. sz. ügyben), amelyre az elvet alkalmazni kell. Mivel a bírói hatáskör kereteiből a jogértelmezés tartalmi korlátai fakadhatnak, indokolt lett volna, hogy a főtanácsnok olyan ítéletek alapján érveljen, melyekben EU-irányelvek érvényességét vizsgálták az elővigyázatosság elve alapján. 
A főtanácsnok az elv hatályának szűkítését egyébként láthatóan szívügyének tekintette, hiszen még azt is megjegyezte, hogy „[a] jogértelmezés egyéb eseteihez hasonlóan, a szóban forgó elv bizonytalan fogalmak vagy kategóriák értelmezésére alkalmazható..."- ez talán már saját, korábbi megállapításaival sincs összhangban. Az elv ugyanis - amint arra korábban már kitértem - a fötanácsnok által levezetettnél jóval szélesebb körben alkalmazható és alkalmazandó (de erre a GMO-irányelv említett, 8. preambulumbekezdése is utal, hiszen aszerint az állandó uniós szabályozás megalapozásánál, a jogintézmények kiválasztásánál is érvényesülnie kellett az elővigyázatosságnak).

Megjegyzi még az indítvány, hogy a két (uniós - tagállami) szint viszonyában, utóbbi alátámasztásakor alacsonyabb lehet a bizonyítási küszöb (például bizonyosság helyett elég lehet valószínűség); ennyiben egyetértek az indítvánnyal. Az uniós jogalkotás, illetőleg az uniós jog értelmezése szempontjából azonban ez semmiféle kötöttséget nem jelent: az uniós jogalkotó maga is kiindulhat alacsony küszöbböl, azaz szigorúbban veheti az elővigyázatosság követelményét, ha úgy látja jónak.

\subsection{A mentesítés oka és annak következménye a tagállami mozgástérre}

Végeredményben a főtanácsnok úgy látta, hogy a felperesek valójában az irányelv átírását szeretnék elérni a bíróságtól, ami (természetesen) lehetetlen. A mutagenezis technikái közt szerinte nem lehet egyéb különbséget tenni, mint ami az irányelvben szerepel, vagyis nincs új szabályozási helyzet (probléma). A fő kérdésre ezért azt a választ javasolta adni, hogy a bíróság ragaszkodjon a mentesülésnek az irányelvben megnevezett feltételeihez; vagyis a mutagenezis valamennyi technikájára - az újakra is - terjedjen ki a mentesülés (a két irányelvi feltétel teljesülése esetén).

Mint említettem, az ügyben több, további kérdés is felmerült. Röviden ezekre is érdemes kitérni, mert az érvek összefüggenek, s maga az elővigyázatosság is további értelmet nyer az indítvány szerint. Fontos kérdés például, hogy a mentesítést miként kell értelmezni. Azzal a jogalkotó úgy döntött, hogy nem kívánja szabályozni a mutagenezist, s átengedi a terepet a tagállamoknak, avagy épp ellenkezőleg, úgy döntött, hogy a mutagenezis biztonságos, mentesítette a követelmények alól, s ez esetben a tagállamok nem vagy csak kivételesen tehetnek intézkedéseket?

Az indítvány az első értelmezést tette magáévá, vagyis azt, hogy a Tanácsnak egyáltalán nem állt szándékában szabályozni a mutagenezist (így azt sem mondta ki, hogy a mutagenezis biztonságos lenne). Ennek alátámasztására a 17. preambulumbekezdés és a mentesítési előírás viszonyára, egész pontosan az öszszefüggés hiányára hivatkozik (aminek a megállapítását a fő kérdéssel összefüggésben már bíráltam).

Egy pillanatra visszatérve a 2.1. pontban írtakra, úgy vélem, e ponton válik érthetővé, miért is állította korábban a fötanácsnok, hogy a preambulum és a mentesítés szabálya nem kapcsolódik össze: saját érvelése kulcselemének a mentesülés értelmezését tekintette, s nem annak a kérdésnek a megválaszolását, hogy a mentesülés kiterjed-e az új technikákra. Mivel a számára fontosabb kérdésben a 17. preambulumbekezdést negligálta, a másik kérdésben - az érvelés koherenciájának megőrzése érdekében - nem állíthatta ennek ellenkezőjét. 
Figyelemre méltó még e körben a mentesítés kapcsán tett megjegyzés, ami tulajdonképp kimondatlanul is az elővigyázatosság elvének ad tág értelmezést: „aligha feltételezhetjük, hogy egy józan jogalkotó valaha is álmodhatna arról, hogy teljeskörüen és a jövöre nézve kijelentse, hogy valami olyannyira biztonságos, hogy egyáltalán nincs szükség a szabályozására sem uniós, sem nemzeti szinten”. Ebből, a mindkét szabályozási szintet érintő kijelentésből azonban az indítvány csak a tagállami jogalkotóra nézve vont le következtetést: végeredményben arra jutott, hogy a tagállamok szabályozhatják a mutagenezist, nincs akadálya, hogy GMOként kezeljék az így előállított szervezeteket, mégpedig nemcsak ideiglenes jelleggel (például moratórium), ${ }^{44}$ hanem akár állandó jelleggel is, feltéve persze, hogy az uniós jog általános követelményeit tiszteletben tartják.

Ez egy messzire mutató következtetés volt, amely a hazai szaktárca figyelmének is a középpontjába került. Vajon tényleg lenne-e mozgástere a tagállamoknak a belső piaci szabadságokat korlátozó szabályokat bevezetni ezen a területen? Avagy, ha valóban szabályozni szeretnék a precíziós mutagenezist, akkor célszerübb-e egymással együttmüködniük $\mathrm{s}$ az uniós szabályozás módosítását kieszközölniük? ${ }^{45}$ Nem csupán arról van-e szó, hogy ezzel a megoldással a főtanácsnok egyszerűen áthárította volna az uniós jogalkotó felelősségét a tagállamokra? Mielőtt e feltételes kérdésekben elmélyednénk, emlékeztetnem kell arra, hogy a probléma megítélése alapvetően az első - a hatályra vonatkozóan feltett - kérdés eldöntésétől függ, s azt a Bíróság a főtanácsnoktól egészen eltérően közelítette meg.

\subsection{A mentesítési szabály időszerüsége és érvényessége}

Végül az elővigyázatosság elve még egy kérdésben kapott szerepet: vajon az irányelvben biztosított mentesítési szabály érvényes-e, tekintettel az új technikák megjelenésére, amelyek megítélésében jelenleg tudományos bizonytalanság áll fenn? (A kérdés mögött az a feltételezés áll, hogy ha az EUMSZ 191. cikkében rögzített elővigyázatossági elv nem érvényesíthető e körben, akkor ezen az alapon az irányelvi szabály megtámadható.) A fötanácsnok - helyesen, a hagyományos szemlélettel szakítva - abból indult ki, hogy egy uniós jogi aktus érvényessége nemcsak az elfogadáskori tények és ismeretek alapján támadható, hanem abban az esetben is, ha a jogalkotó elmulasztja azt a kötelezettségét, hogy a jogszabályt „...észszerü keretek között naprakészen tartsa". Ezen általános kötelezettséghez jelen esetben az elővigyázatosság elvének érvényesítése kapcsolódik mint speciális kötelezettség. Az elővigyázatossági elvvel érintett szakterületeken a szabályozás naprakészen tartása kulcsfontosságú.

44 Ez fontos értelmezési segítség lehet a tagállamoknak. Figyelemre méltó egyébként, hogy a francia Államtanács erre általánosságban kérdezett rá (ami a Bizottság szerint nem megengedhető, hipotetikus kérdés), a főtanácsnok azonban a felperesek által követelt moratórium esetleges bevezetése miatt tartotta befogadhatónak a kérdést.

45 A tárca képviselőivel e kérdéseket latolgattuk az említett műhelykonferencián. Megjegyzendő, hogy e kérdések messze túlmutatnak a GMO-ügy jelentőségén a tagállami és az uniós jog szempontjából. 
Elvben ezért elképzelhető, hogy a jogszabály utólagos felülvizsgálatának elmulasztása miatt az érintett norma érvénytelenségét állapítsák meg, de csak kivételesen, szélsőséges esetben, amikor „...a megváltozott valóság és a gyakorlatilag elavult jogszabály között egyértelmü és nagymértékü disszonancia áll fenn". Erről azonban a fötanácsnok szerint a jelen ügyben nem lehet szó. A 2001/18/EK irányelv ugyanis már maga is felülvizsgálat eredménye, illetve a GMO-kra vonatkozó joganyag az irányelv 2001-es elfogadása óta is többször változott, például 2015-ben oly módon, hogy a tagállamok immár több okra hivatkozva is megtilthatják területükön a GMO-k termesztését. Az, hogy a tagállamoknak is van szabályozási kötelezettsége (nem csak lehetősége) - akár az elővigyázatosság elve alapján -, csökkenti az uniós jogalkotó felelősségét.

Emellett a fötanácsnok ismét hivatkozott arra, hogy a védzáradékkal kapcsolatos bírói gyakorlat ${ }^{46}$ szerint ahhoz, hogy az elővigyázatosság elve alapján intézkedést lehessen hozni, konkrét kockázatokat kell azonosítani, amelyekröl jelen esetben igen csekély az információ. Ezen utóbbi megközelítés egyoldalúságával kapcsolatban (ti. hogy nem lehet ezzel az uniós jogalkotó kötelezettségét leírni) már korábban kifejtettem álláspontomat. Egyet lehet érteni viszont azzal, hogy ez a kötelezettség megoszlik az uniós és a tagállami szint között.

Egy megjegyzést fúznék még ehhez: annak ellenére, hogy a bíróság - adott esetben, a hatáskörének korlátai miatt - nem állapíthatja meg egy uniós norma érvénytelenségét, az annak felülvizsgálatára vonatkozó jogalkotói kötelezettség már fennállhat, s érvényesítésének lehetnek más eszközei.

\section{Röviden az Európai Unió Bíróságának a C-528/16 ügyben hozott ítéletéről ${ }^{47}$}

Rendkívül nagy jelentőségủ ítéletről van szó, amely elé sokan azzal a várakozással tekintettek, hogy majd ez dönti el végleg a génszerkesztés jogi megítélésének kérdését. ${ }^{48}$ Mindazonáltal e tanulmánynak nem az ítélet elemzése a célja (azt bizonyosan sokan elvégzik majd a közeljövöben); az ítéletet csupán annyiban hivatkozom és értékelem, amennyiben az eddig kifejtettek alátámasztásához vagy kiegészítéséhez szükséges.

Mint arra a bevezetőben már utaltam, a Bíróság a főtanácsnoki indítvány érvelését nem fogadta el. Az első kérdésben úgy foglalt állást, hogy a mutagenezis nem generálisan, hanem csak azon technikáit illetően esik ki az irányelv hatálya alól, amelyeket "már hagyományosan számos alkalmazásban használtak, és amelyek biztonságossága régóta bebizonyosodott". (A mutagenezisen belül a Bíróság nem

46 TAHYNÉ KovÁcs Ágnes: GMO-kkal kapcsolatos egyes európai bírósági jogesetekről és tanulságaikról. In: Láncos Petra Lea (szerk.): Válságban az Európai Unió. Pázmány Press, Budapest, 2014, 59-85; FodoR (2012): i. m., 65-75.

47 Az ítéletnek jelenleg (2018. 07. 30.) csak az ideiglenes szövegváltozata érhető el (az EBHT-ban még nem tették közzé). ECLI:EU:C:2018:583.

48 Griebsch: i. m., 100. 
tett különbséget az irányelv I. B. mellékletében említett [a kizárólagosságot biztosító] feltételek szerint, azokat adottnak vette.)

Így az irányelv 17. preambulumbekezdését nemcsak hogy összekapcsolta a mentesítési szabállyal, de ráadásul érdemi, normatív jelentőséget tulajdonított neki (az ítélet 44-45. pontjainak igehasználata egyértelmú e tekintetben: aszerint a preambulumbekezdés „...kimondta [...] meghatározta...”). A bíróság úgy ítélte meg, hogy a mutagenezis új technikáinak hasonló kockázatai lehetnek, mint a transzgenezis eljárásainak, amit azzal is aláhúz az ítélet, hogy „ezen új technikák, illetve módszerek kifejlesztése olyan ütemben és arányban teszi lehetővé géntechnológiával módosított fajták előállitását, amelyek nem mérhetök össze a véletlenszerü mutagenezis hagyományos módszereinek alkalmazásából eredőekkel" (ítélet, 48. pont). Az érvelésből kiemelésre érdemes még ehhez kapcsolódóan a fentiekben már többször is említett elövigyázatossági elv, valamint az irányelv 55. preambulumbekezdésének a hivatkozása, amely ti. „...hangsúlyozza a GMO-k fejlesztése és felhasználása szoros nyomon követésének fontosságát". Ebből, illetve az irányelv céljaiból (emberi egészség és környezet védelme) is következik, hogy az irányelvi követelmények alóli kivételeket szigorúan (szorosan) kell értelmezni; a mutagenezis eredményeinek - minden feltétel nélküli - kivétele a szabályozás hatálya alól az említett elvvel és célokkal ellentétes volna (51-53. pont).

A fajtajegyzékbe való felvétel - a 2002/53 irányelv alkalmazása - kapcsán (vagyis a második kérdésben) a Bíróság ehhez hasonlóan foglalt állást. Megemlítésre érdemes, hogy a fajtajegyzékről szóló irányelv több olyan rendelkezést is tartalmaz (például a GMO-k fogalma, vagy az emberi egészséget és a környezetet érő káros hatások kiküszöbölésére irányuló, valamennyi megfelelő intézkedés szükségessége tárgyában), amelyek még a régi, időközben hatályon kívül helyezett 90/220 GMOirányelvre utalnak tovább. A Bíróság fontosnak tartotta kiemelni, hogy az ilyen utalásokat a hatályos GMO-irányelvre vonatkozó hivatkozásnak kell tekinteni (57-59. pont). Így például megállapítja az ítélet, hogy bár a 2002/53 irányelv nem hivatkozik a hatályos GMO-irányelv mentesítési szabályaira, azt viszont rögzíti, hogy a géntechnológiával módosított fajták esetében el kell végezni a 90/220 irányelvben megállapítottakkal egyenértékü környezetvédelmi kockázatfelmérést. A GMO-irányelv szerinti engedélyezési eljárás (a Bíróság korábbi gyakorlata alapján) pedig megfelel a fajtajegyzékről szóló irányelv követelményeinek. A követelményekbe a GMOirányelv szerinti mentesítés is beleértendő, de csak ugyanazokkal a feltételekkel (hagyományosan használt, bizonyítottan biztonságos eljárások), mint amelyeket az első kérdésben megállapított (63-68. pont).

Az eddigiek alapján tehát a Bíróság szerint a mutagenezis kipróbált, biztonságos eljárásai (helyesebben azok eredményei) nem esnek a szabályozás hatálya alá; $s$ ezek tekintetében értelmezhető a harmadik kérdés, amelyik a tagállami mozgástérre irányul. A Bíróság (a főtanácsnokkal egyezően) arra jutott, hogy a tagállami mozgástér fennáll - az uniós jog és különösen az áruk szabad mozgására vonatkozóan az EUMSZ 34-36. cikkben elöírt szabályok tiszteletben tartása mellett.

A negyedik kérdés megválaszolását - tekintettel arra, hogy értelmezése szerint az irányelv nem zárja ki a hatálya alól a mutagenezis technikáit, illetve az annak módszerei útján nyert szervezetek összességét, az alkalmazott technikától függetlenül - nem tartotta szükségesnek. 


\section{Zárszó}

Míg a hazai szabályozás alapján eddig is elmondható volt, hogy a génszerkesztés (legyen szó akár régebbi vagy újabb generációs technikákról) nemkívánatos a mezőgazdaságban, az uniós jog olyan értelmezése, amely e technikák eredményeire nézve a szigorú engedélyeztetési és egyéb követelmények alkalmazásának szükségességét eredményezi, csak az Európai Unió Bírósága 2018. július 25-ei ítélete alapján mondható egyértelműnek. Az ítélet bezárt egy kiskaput, s így, amíg csak az új és újabb GM-eljárások tudományos megítélése nem válik egyöntetüen pozitívvá, addig ez a kapu a jövőben is zárva marad (azaz: az új technikák eredményei is engedélykötelesek). Hatalmas ugyanakkor a végrehajtásban közremüködő hatóságok felelőssége, hiszen a GM-fajták száma egyre csak nő, azokat a világ számos országában jelölni sem kell, s egyre terjednek az olyan eljárások is, amelyek nyomát az adott fajta génállományában csak rendkívül nehezen lehet felismerni. ${ }^{49} \mathrm{~A}$ GMOháború ${ }^{50}$ nem ért véget.

Mindebből hazánk számára is levonhatók fontos tanulságok. Mindenekelőtt az, hogy bár az utóbbi években igen erős támogatást kapott a precíziós nemesítés a hazai tudományosság s az agrártermelők (például a Nemzeti Agrárgazdasági Kamara) részéről is (akik, például az ún. precíziós mezőgazdaság igényeit szerették volna a termesztés szempontjából kedvező tulajdonságú, génszerkesztett fajtákból kielégíteni, illetve a hazai növénytermesztés versenyképességét látják veszélyeztetve a precíziós nemesítés nélkül), ${ }^{51}$ az EU-jog oldaláról nem érkezett olyan impulzus, amely a hazai jogalkotót a jelenlegi korlátok, illetve tilalmak feloldására ösztönözné. További következtetés, hogy a nemzeti géntechnológiai szabályozást érdemes a géntechnológia rohamos fejlödéséhez igazítani, ${ }^{52} \mathrm{~s}$ a (jelenleg EU-s összehasonlításban kirívóan alacsony létszámú) hazai génügyi hatóságot mind létszámában, mind szakmai és infrastruktúra-hátterét tekintve megerősíteni.

49 A géntechnológiai fejlődésnek a most szóban forgó technikák (mint különösen a CRISPR-Cas9) egy új hullámát indították el. LedFORD, Heidi: CRISPR: Gene Editing is just the Beginning. Nature, 2016. 03. 10., 516, https://www.nature.com/polopoly_fs/1.19510!/menu/main/topColumns/topLeftColumn/pdf/531156a.pdf (2018. 07. 30.).

50 A „GMO-háború” kifejezés használatához lásd http://ecolounge.hu/nagyvilag/a-gmo-meccs-meg-tart-igyteszi-tonkre-a-kornyezetet-a-genmodositas; illetve RAIsz Anikó: GMO-támadás, mint az agresszió újabb formája? Polgári Szemle, 2012/8, https://polgariszemle.hu/archivum/118-2012-junius-8-evfolyam-1-2-szam/ objektiv/482-gmo-tamadas-mint-az-agresszio-ujabb-formaja (2018. 07. 27.).

51 PI. még 2018 júliusában is így nyilatkozott a szervezet egyik vezetője, https://www.agrarszektor.hu/noveny/ kerteszeti-skanzen-leszunk-a-genszerkesztesben-latjak-a-kiutat.11154.html (2018. 07. 27.).

52 A hazai szabályozás felülvizsgálata már egy 2017. évi konferencián is felmerült, Id. http://www.nak.hu/ agazati-hirek/mezogazdasag/146-novenytermesztes/93970-uj-gmo-szabalyozas-magyarorszagon (2018. 07. 30.). Olyan szempontok merültek fel, mint pl. az állatokra való kiterjesztés vagy az ön- és idegenbeporzó növényfajok közti differenciálás. 


\begin{abstract}
The rapidly developing gene manipulation techniques (more recently "gene editing") have long been controversial, which is reflected in the evolution of legal regulation in Europe. Hungary's Fundamental Law (Art. XX.) clearly states that Hungarian agriculture desires to remain free from genetically modified organisms. According to the Hungarian Academy of Sciences (MTA resolution, 2017), the results of the new techniques (without transgenic implantation) are not regarded as GMOs (by the proper application of the genetic engineering law), these new techniques are not governed by the provisions of the Fundamental Law. Recently, a lawsuit was filed before the Court of Justice of the European Union in which the main question was whether GMOs should be considered the result of new techniques (if not, they do not need to be licensed). In the light of a detailed analysis of the precautionary principle, the study examines the question of whether genetic engineering or its results cover the scope of the legislation. According to the author, this question (as long as the revision of the regulation is not on the agenda) is not for the genetic technologists and plant breeders, but for the lawyers to decide. The conclusion of the study is that genetic engineering, respectively its results are subject to the regulation.
\end{abstract}

